\title{
THE BRICS DEVELOPMENT AND EDUCATION COOPERATION AGENDA
}

\author{
T. Muhr \\ Habib University Karachi, Karachi, Pakistan \\ University of Nottingham, Nottingham, UK \\ M.L.N. de Azevedo \\ Universidade Estadual de Maringá, Maringá, Brasil
}

\begin{abstract}
Framed by contested interpretations of the Buenos Aires Plan of Action, this article aims to conduct a first evaluation of the BRICS development and education cooperation agenda as a case study of South - South cooperation (SSC). Methodologically, as a theory-based case study that integrates exploration with illustration and explanation, an analytical review of Anglophone academic BRICS education literature combines with contents and discourse analysis of BRICS cooperation documents from 2009-2017. While the mainstream international and comparative education literature, embedded in (neo)realist international relations theory, limits itself to individual BRICS member country case studies, a critical approach associated with counter-dependency theory in conjunction with SSC as an analytical category transcends methodological nationalism by exploring common agendas, projects, relations and potential synergies generated within BRICS as an analytical unit. While a more pronounced and assertive BRICS SSC agenda has emerged over time, the findings do not permit to unambiguously conclude that BRICS education cooperation produces a counter-structure to the neoliberal global governance of education. However, we nonetheless perceive BRICS education cooperation as contributing to building a counterdependency structure. Future empirical research will have to inquire about the de facto implementation of this agenda.
\end{abstract}

Key words: BRICS; counter-dependency; development; education; South—South cooperation

\section{INTRODUCTION}

The Buenos Aires Plan of Action (BAPA) ${ }^{1}$ has not been uncontroversially discussed in the academic South-South cooperation (SSC) literature. On the one hand, the Plan is viewed as "a key reference point for contemporary SSC efforts" [see also Birn et al. 2017: 43], "the foundational milestone of contemporary SSC" [Report on South - South 2017: 11], and having "stipulated the guiding principles of South-South cooperation" [Silva 2018: 65]. These attributions derive from the BAPA's reiteration of the fundamental SSC principles of solidarity, complementarity, equal rights, national sovereignty, non-interference and economic independence ${ }^{2}$, while promoting knowledge and experience transfer and sharing for mutual benefit", "to achieve national and collective self-reliance and to the need to bring about the new international economic order [NIEO]"4 [Birn et al. 2017: 43;

1 UNOSSC (1978). Plan of Action for Promoting and Implementing Technical Co-operation among Developing Countries (TCDC). URL: https://www.unsouthsouth.org/bapa40/documents/ buenos-aires-plan-of-action/ (accessed 23.06.2016).

2 Ibid. Points 13, 15b, 16.

3 Ibid. Points 5, 15 b.

${ }^{4}$ Ibid. Point 12. 
Report on South-South 2017: 26]. Following the 1955 Bandung Conference and the formation of the Non-Aligned movement (NAM) and the Group of 77 (G77), the Third World quest for greater political and economic independence or autonomy from the capitalist core peaked in the 1970s demand for an NIEO [Gosovic 2016]. While the BAPA itself does not refer to "horizontal cooperation", which has become almost synonymous to SSC in contradistinction to "vertical" official development assistance within the framework of the OECD-DAC (associated with conditionalities), the origin or popularisation of the notion of "horizontal cooperation" has been ascribed to the context of the Buenos Aires Conference [Esteves, Assunção 2014; Martín 2016].

From a critical, dependency theoretical perspective, on the other hand, the BAPA has been criticised for actually constituting a "regression" in the struggle for South selfdetermination and the aspired "restructuration of the North-South relations" associated with the NIEO project [Ernst 1979: 1396-1397]. First, as one moment in the West's counter-offensive "to neutralise the NIEO" [Martín 2016: 67], the BAPA reduced SSC to technical cooperation, thus undermining the larger vision of collective self-determination and restructuration of the world economy, instead promoting the South's integration into "a new international" (i.e. the global) division of labour [Amin 1980; Ernst 1979]. Second, by declaring SSC a "complement" rather than "substitute" for North-South cooperation $^{5}$ [Report on South—South... 2017: 29], the BAPA laid a foundation for "triangular cooperation" [Report on South—South... 2017: 26; Silva 2018: 65], which, arguably, integrates SSC in a "subaltern fashion" into the OECD-DAC regime [Martín 2016: 58]. Strongly promoted since the late 1990s as part of the neoliberal global governance of development, in triangular cooperation international agencies and governments of the North act as "brokers" for "best practice transfer" among developing countries [Sá e Silva 2009].

Framed by these discussions, this article conducts a first evaluation of the BRICS ${ }^{6}$ development and education cooperation agenda. Methodologically, as a qualitative theory-based case study that integrates exploration with illustration and explanation [Hesse-Biber 2017; Yin 2009], an analytical review of Anglophone academic BRICS education literature combines with contents and discourse analysis of BRICS cooperation documents from 2009-2017 . While the mainstream international and comparative education literature, embedded in (neo)realist international relations theory, limits itself to individual BRICS member country case studies, a critical approach associated with counter-dependency theory in conjunction with SSC as an analytical category transcends

5 UNOSSC (1978). Plan of Action for Promoting and Implementing Technical Co-operation among Developing Countries (TCDC). Point 8. URL: https://www.unsouthsouth.org/bapa40/ documents/buenos-aires-plan-of-action/ (accessed 23.06.2016).

6 "BRIC" (Brazil, Russia, India, China) formally met for the first time through their foreign ministers in September 2006. In 2010, South Africa joined to form "BRICS".

7 The documentary analysis included the nine BRIC(S) annual summit declarations and respective Action Plans from 2009-2017 (Action Plans have been presented only from the $1^{\text {st }}$ BRICS meeting in 2011 onwards), as well as six education-related documents between 2015-2017. Dialogue between SSC/BRICS literature and the documentary analysis generated 47 conceptual categories (key terms and concepts) for systematic quantitative analysis combined with interpretative analysis [Mason 2002]. 
methodological nationalism by exploring common agendas, projects, relations and potential synergies generated within BRICS as an analytical unit. While a more pronounced and assertive BRICS SSC agenda has emerged over time, the findings do not permit to unambiguously conclude that BRICS education cooperation produces a counterstructure to the neoliberal global governance of education. However, we nonetheless perceive BRICS education cooperation as contributing to building a counter-dependency structure.

\section{CONCEPTUAL CLARIFICATIONS}

An authoritative definition of "best practice transfer", or "policy transfer", views this as a "process by which knowledge about policies, administrative arrangements, institutions and ideas in one political system (past or present) is used in the development of policies, administrative arrangements, institutions and ideas in another political system" [Dolowitz, Marsh 2000: 5]. "Transfer", however, can be of a more or less coercive nature, ranging from voluntary "lesson-drawing" to direct and indirect imposition through, inter alia, international institutional pressures (e.g., OECD, IMF, G-7, think tanks), transnational corporations, and mechanisms such as conditionalities tied to loans and grants [Dolowitz, Marsh 2000]. As a relation of inequality regarding actor autonomy, the coercive element in "transfer" underscores the difference between triangular collaboration and SSC as a "counter-dependency" strategy: unlike dependency as a relation of inequality that implies "the absence of actor autonomy", dependence connotes "asymmetric interdependence" which, as a relation of "mutual control" and "reliance", is legitimate if consensual [Caporaso 1978]. Since autonomy or "total selfreliance" appears illusionary for especially resource-poor nations, "controlled dependence" is a more egalitarian relation as the partners can "affect the fundamental nature of their relationships" [Erisman 1991: 143]. While the BAPA acknowledged this by stating that interdependence "demands sovereign and equal participation in the conduct of international relations and the equitable distribution of benefits" should not suggest that the solidarity and "win-win" relations associated with SSC could per se be equated with altruism and absence of conflicting commercial and political interests and other power asymmetries [Muhr 2016]. Rather, decisive is whether South-South interdependences generate South counter-dependency - that is, collective self-reliance. Subsequently, a further major criticism of "transfer" views this as a depoliticisation of SSC as merely a technicality "no longer rooted in the political mobilization of the South" [Sá e Silva 2009: 51]. The instrumentalisation, cooptation and reconceptualisation of South-South cooperation as transfer rather than "collective process" undermines the "organic, political and potentially innovative nature of SouthSouth cooperation" [Jules, Sá e Silva 2008: 58].

International and comparative education literatures echo these discussions. With the World Bank adopting its self-styled role as a global "knowledge bank" in the 1990s,

${ }^{8}$ UNOSSC (1978). Plan of Action for Promoting and Implementing Technical Co-operation among Developing Countries (TCDC). Point 2. URL: https://www.unsouthsouth.org/bapa40/ documents/buenos-aires-plan-of-action/ (accessed 23.06.2016). 
it simultaneously assumed the role of a "monitor and lender of "best practices"" [SteinerKhamsi 2007: 285], with other organisations of global governance, including Transparency International and United Nations (UN) agencies, following suit. Together with such donor conditionalities as efficiency and effectiveness (performance enhancement) and practices of benchmarking, ranking and scoring associated with "international standards", best practice transfer has been considered a "unidirectional" mechanism that advances "interstate competition, coercion and convergence" [Steiner-Khamsi 2007: 285286]. Subsequently, UNESCO has also adopted best practice transfer "as a tool within its overall EFA (Education for All) program and strategy" [Sá e Silva 2009: 50], and even in documents that make reference to the post-World War II spirit of SSC, such as the UNESCO BRICS: Building Education for the Future report ${ }^{9}$, the view of SSC as a technicality rather than political process dominates, stating that BRICS should "learn from one another" for improvement of the "effectiveness" of their cooperation programmes $^{10}$.

While BRICS is a state-led South-South project, conceptual rigour requires distinguishing two models of education governance: neoliberal "transnationalisation" in the interests of transnational corporations, including the establishment of North university subsidiaries in the South and the sale of academic licences; and "international" and "horizontal cooperation", conceived of as "respectful of the idiosyncrasies and identities of the participating countries" [Tünnermann Bernheim 2009: 51—52 ]" . As has been shown with respect to Brazil, the two strategies of "commodification and solidarity" can coexist in national education policies [Azevedo 2015]. It is hereby important to highlight that much of the international and comparative education literature speaks of "internationalisation" (e.g., with respect to student mobility) when actually referring to transnationalisation.

\section{BRICS EDUCATION LITERATURE: AN ANALYTICAL REVIEW}

The Anglophone academic literature on education in BRICS ${ }^{12}$ follows the dominant mainstream approach to BRICS (in fact, to SSC generally) by adopting a methodologically nationalist "country" approach as a basis for comparison [Robertson, Dale 2008], coupled with (neo)realist underpinnings of nation-state competition and behaviourist "soft power", i.e. states viewed as subjects that have the ability to affect other states to "obtain preferred outcomes by co-option and attraction" [Nye 2010: 216]. Consequently, major publications on education in BRICS are simply collections of individual country studies without exploring relations, common agendas and synergies generated. For

9 UNESCO (2014). BRICS: Building Education for the Future. Priorities for National Development and International Cooperation. Paris: UNESCO. URL: http://unesdoc.unesco.org/images/ 0022/002290/229054e.pdf (accessed 23.06.2016).

10 Ibid. P. 3.

11 Following globalization, human geography and global governance literatures, "international" connotes official relations between national governments and/or inter-nation-state relations; "transnational" refers to border-crossing forces, institutions and processes, i.e. relations that traverse or interpenetrate national boundaries and territories.

12 This body of literature is limited in quantitative terms. However, no claim to completeness of the review presented here is made. 
example, Carnoy et al. compare "BRIC state behaviour... to develop a broad picture of the higher education system in each country" [Carnoy et al. 2013: 26, 4]. Altbach and collaborators compare "the academic systems and challenges of each of the BRIC countries", pointing to "aggressive international strategies" to "compete with each other for prestige and placement in the global rankings" [Altbach et al. 2013: VIII-IX]. Similarly, Schwartzman et al's "comparative" compilation restricts itself to "national perspectives" of "the policies being implemented by the BRICS's governments" [Schwartzman et al. 2015: 5-6]. Oleksiyenko and Yang's exploration of BRICS members' higher education "internationalization policies" is mostly concerned with transnational, North-oriented and neoliberal cooperation initiatives and "soft power diplomacies" [Oleksiyenko, Yang 2015: 3]. Finally, by reference to the two contributions in their collection that engage in some detail with South-South education cooperation by BRICS members, Cheng and Chan conclude that "China and India are intent on aid intervention in education as a soft power to reidentify themselves as education hubs and regional leaders exerting greater influence over developing Asia" [Cheng, Chan 2015: 246].

This literature is problematic in two distinct though interrelated ways. Inherently Western-centric, it takes the established global ranking and benchmarking regimes and/or North (higher) education systems as references for comparison and prescription. As Carnoy et al. insist, "the BRIC countries will likely have to make some major investments in order to bring their higher education systems in line with the U.S./ European models of research universities" [Carnoy et al. 2013: 14]. In addition, the (neo)realist view of nation-states as homogenous, rationally behaving units locked into permanent struggle for survival and domination ("power politics") [Buzan et al. 1998] conjoined with the "soft power" approach downplays, if not ignores altogether, the relevance of SSC as an analytical category ${ }^{13}$. Within this approach, SSC is a state's tool to pursue its interests, and "soft power" depicts power as a unidirectional mechanism (rather than relational-dialectical) in which the affected is inherently objectified. Transferred from USA/Western foreign policy discourse and experience, "soft power" in relation to SSC has been rejected for its "conceptual inadequacy" [Birn et al. 2017: 39], as it ontologically excludes "real cooperation" [Jules, Sá e Silva 2008: 53]. As King [King 2013] points out in his comparison of OECD-DAC and Chinese "human resource development" cooperation, "soft power" implies a "winner-loser" relation that rules out the essence of SSC, namely, of common or mutual interests (such as the objective of self-reliance), solidarity, equality, win-win cooperation and mutual benefit [King 2013: 10 - 11, 193-194] ${ }^{14}$. Within an SSC framing, "policy learning" then would means mutual or bidirectional learning, rather than "policy transfer".

${ }^{13}$ See, for instance, Chatin and Gallarotti's introduction to a special issue on BRICS and soft power that dismisses SSC as simply "rhetoric" [Chatin, Gallarotti 2016: 337]. For exceptions that transcend methodological nationalism and examine soft power in relation to BRICS as an entity, nonetheless omitting SSC from the discussion, see [Gallarotti 2016] and [Stuenkel 2016] in that same issue.

${ }^{14}$ King, however, detects contradictions in China's more recent official South-South cooperation discourse, which he attempts to resolve by proposing an ambiguous "soft soft power" or "soft power 'with Chinese characteristics'". 
The following analysis of the BRICS education agenda responds to the previously discussed literature in two main ways: it overcomes the reduction of education to higher education by highlighting the more holistic approach to education adopted by BRICS; and it transcends the methodologically nationalist approach by exploring common projects, relations and potential synergies within BRICS as an analytical unit. Thus, it challenges such premature judgments that "grouping them [the BRICs countries] for analytical purposes in higher education is simply not relevant" [Altbach, Bassett 2014: 2]. Central to the inquiry is whether BRICS education cooperation contributes to building a counter-dependency structure. Strategically, as Ernst [Ernst 1979: 1399] proposed decades ago, education for self-determination would require joining resources and experiences for selectively delinking from the Western education systems.

\section{BRICS: TOWARDS A COMMON EDUCATION COOPERATION AGENDA}

Analysis of the BRIC(S) annual summitry declarations and respective Action Plans 2009-2017 reveals a discursive shift towards a more pronounced and assertive SSC agenda over time (Table 1). While this is a hybrid discourse that also integrates elements of the "best practice" discourse, the SSC discourse clearly dominates, especially from 2014/2015 onward. In this process, "cooperation" as a South-South relations principle itself moved centre-stage, from a marginal mention in Point 12 in the 2009 Joint Statement to Points 1 and/or 2 in the subsequent declarations. However, while direct references to "South-South cooperation" and "win-win" relations entered the discourse in 2015, these are absent in subsequent declarations (Table 1), which might be related to government changes in recent years, particularly in Brazil.

Table 1

Selected indicators of SSC ideas, principles and practices (quantitative increase over time)

\begin{tabular}{|l|c|c|c|c|c|c|c|c|c|}
\hline \multicolumn{1}{|c|}{ Indicators } & 2009 & 2010 & 2011 & 2012 & 2013 & 2014 & 2015 & 2016 & 2017 \\
\hline Friendship* & - & - & - & - & - & 1 & 1 & 1 & 5 \\
\hline South-South cooperation & - & - & - & - & - & - & 2 & - & - \\
\hline Win-win relations & - & - & - & - & - & - & 1 & - & - \\
\hline Solidarity & - & 4 & 1 & 1 & 2 & 1 & 4 & 5 & 4 \\
\hline $\begin{array}{l}\text { Partner/partnership (among } \\
\text { BRICS, excl. PPPs)** }\end{array}$ & 1 & - & 1 & 2 & 4 & 6 & 6 & 12 & 18 \\
\hline Complementarity & - & - & - & 2 & 1 & 2 & 1 & 1 & 3 \\
\hline Convergence (objective) & - & - & - & - & - & - & 1 & 1 & 1 \\
\hline $\begin{array}{l}\text { Coordination (intra-BRICS } \\
\text { principle/objective) }\end{array}$ & 1 & 1 & 1 & 1 & 1 & 4 & 11 & 5 & 8 \\
\hline $\begin{array}{l}\text { Synergies (use/creation } \\
\text { within BRICS) }\end{array}$ & - & - & - & 2 & - & - & 1 & - & 3 \\
\hline $\begin{array}{l}\text { Mutual/shared benefit(s) } \\
\text { (direct reference to) }\end{array}$ & - & - & 1 & - & 1 & 3 & 5 & 4 & 5 \\
\hline $\begin{array}{l}\text { Common/mutual/shared } \\
\text { interests (BRICS/South) }\end{array}$ & 1 & 1 & 1 & - & 1 & 1 & 10 & 2 & 3 \\
\hline $\begin{array}{l}\text { Sovereignty/non-interfe- } \\
\text { rence/equality/equity } \\
\text { in international relations }\end{array}$ & 1 & 4 & 2 & 2 & 3 & 8 & 24 & 18 & 23 \\
\hline
\end{tabular}

Source: Produced by authors. *friendship as used in Chinese SSC [King 2013]; ** partner/partnership as distinct to conventional (OECD-DAC) donor-recipient relations and the global promotion of neoliberal public-private partnerships (PPPs).

NOTE: These are absolute figures. The ratios between words total and occurrences of the SSC indicators in the annual summitry declarations increased from 0.0040 in 2009 to 0.0099 in 2017. 
Despite echoing the dominant international development cooperation discourse by declaring SSC as merely a "complement" to North-South cooperation ("the main channel of international development cooperation") ${ }^{15}$, "triangular" collaboration is entirely absent in the BRICS discourse. This underscores the claim of BRICS as a "strategic cooperation" and "strategic partnership" project ${ }^{16}$ for "common development" 17 .

Moreover, since 2014, BRICS has adopted a holistic approach to human rights, placing equal emphasis on "civil, political, economic, social and cultural rights, as well as the right to development"18. By referring to the "right to development", BRICS evokes the 1986 UN Declaration on the Right to Development, which relates to the "social and international order", as it grants the "collective rights of peoples (of the South)", i.e. "collective solidarity rights vis-à-vis the peoples of the North" [Nowak 2003: 24; Santos, 2002: 293-295]. That is, "the right of peoples to self-determination" (political, economic, social, cultural), which has been a cornerstone of SSC since the 1955 Bandung Conference [Phạm, Shilliam 2016]. Thus, BRICS' call for the "right to development" can be understood as an implicit resumption of the South's struggle for a "new international economic order [NIEO] based on sovereign equality, interdependence, mutual interest and co-operation among all States" $"$.

The hybridity of the BRICS discourse derives from reference to "best practices", with one to three occurrences in each of the BRICS declarations between 2012-2017. However, out of a total of 12 instances, ten refer to mutual "sharing" and "exchanging", which may be viewed as compatible with the South-South principle of non-imposition. The other two instances refer to "learning" from "best practices available" ${ }^{20}$ and to "exploring the possibilities of skills development cooperation through implementation

15 BRICS (2015a). Ufa Declaration \& Action Plan. Point 66. Ufa, 9 July. URL: http://www.brics.utoronto.ca/docs/150709-ufa-declaration_en.html (accessed 23.02.2016).

16 BRICS (2017b). BRICS Leaders Xiamen Declaration + Action Plan. Xiamen, 4 September. URL: http://mea.gov.in/Uploads/PublicationDocs/28912_XiamenDeclaratoin.pdf (accessed 19.09.2018).

${ }^{17}$ BRICS (2011). Sanya Declaration \& Action Plan. Sanya, 14 April. URL: http://www.brics.utoronto.ca/docs/110414-leaders.html (accessed 02.03.2016); BRICS (2012). Delhi Declaration \& Action Plan. New Delhi, 29 March. URL: http://www.brics.utoronto.ca/ docs/120329-delhi-declaration.html (accessed 23.02.2016); BRICS (2017b). BRICS Leaders Xiamen Declaration + Action Plan. Xiamen, 4 September. URL: http://mea.gov.in/Uploads/Publication Docs/28912_XiamenDeclaratoin.pdf (accessed 19.09.2018); BRICS (2016c). Goa Declaration + Action Plan. Goa, 16 October. URL: http://www.brics2018.org.za/sites/default/files/documents/ Goa\%20Declaration.pdf (accessed 19.09.2018).

18 BRICS (2015a). Ufa Declaration \& Action Plan. Point 10. Ufa, 9 July. URL: http://www.brics.utoronto.ca/docs/150709-ufa-declaration_en.html (accessed 23.02.2016).

${ }^{19}$ United Nations (1986). Declaration on the Right to Development. United Nations General Assembly, A/RES/41/128, Article 3.3. 97th Plenary Meeting, 4 December. URL: http://www.un.org/ documents/ga/res/41/a41r128.htm (accessed 23.06.2016). This indivisibility of the various human rights dimensions diverges from the liberal ideology, which "willfully" prioritises civil and political rights, suggesting that the others would follow later (which, however, is not the case) [Santos 2002: 293]. For inevitable contradictions and potentially mutual exclusiveness in efforts of simultaneously realising different dimensions of human rights [Lalander, Lembke 2018].

${ }^{20}$ BRICS (2012). Delhi Declaration \& Action Plan. Point 44. New Delhi, 29 March. URL: http://www.brics.utoronto.ca/docs/120329-delhi-declaration.html (accessed 23.02.2016). 
of the international best practices" 21 , which again connote a more voluntary process (mutual learning), rather than coercive transfer. Hierarchically, in all instances, these "best practice" discourse elements are introduced only further down in the texts after SSC has been established as the overall frame of reference (on hierarchy and hybridity in discourse studies [Fairclough 2003]). In fact, the replacement of "best practices" by "good practices" and "effective practices" in both the 2017 general summit and the education declarations ${ }^{22}$ suggests a delinking from the dominant policy discourse. In sum, the BRICS discourse strongly suggests an understanding of SSC as collective process, rather than merely a technicality, with elements of greater (collective) selfreliance.

Materially, this translates into the construction of a counter-dependency structure for "structural transformation" 23 guided by the "common" or "shared vision" 24 of a "more just, equitable, fair, democratic and representative international political and economic order" 25 . While industrialisation (for "value addition" and integration in "Global Value Chains") is identified as a "core pillar" in this effort ${ }^{26}$, of equal importance is the ongoing transformation of the global governance regime. In this respect, in reaction to the reluctance of North governments to "reform" (i.e. democratise) the World Bank and the IMF, most vocally called for by the BRIC(S) between 2010 and 2012 alongside "a comprehensive reform of the UN, including its Security Council"27, the establishment of the "New Development Bank" and the "Contingent Reserve Arrangement (CRA) amongst BRICS countries" emerged on the agenda in 2012, and the New Development Bank has been operational since $2015^{28}$ [Cooper 2017]. Political mobilisation of the South for "redressing North-South development imbalances" 29 involves deepening cooperation with non-BRICS developing countries, referred to as "BRICS Plus cooperation"

${ }^{21}$ BRICS (2015a). Ufa Declaration \& Action Plan. Point 63, with respect to education. Ufa, 9 July. URL: http://www.brics.utoronto.ca/docs/150709-ufa-declaration_en.html (accessed 23.02.2016).

${ }^{22}$ BRICS (2017b). BRICS Leaders Xiamen Declaration + Action Plan. Xiamen, 4 September. URL: http://mea.gov.in/Uploads/PublicationDocs/28912_XiamenDeclaratoin.pdf (accessed 19.09.2018).

${ }^{23}$ BRICS (2016c). Goa Declaration + Action Plan. Point 26. Goa, 16 October. URL: http://www.brics2018.org.za/sites/default/files/documents/Goa\%20Declaration.pdf (accessed 19.09.2018).

${ }^{24}$ BRICS (2016c). Goa Declaration + Action Plan. Point 6. Goa, 16 October. URL: http://www.brics2018.org.za/sites/default/files/documents/Goa\%20Declaration.pdf (accessed 19.09.2018); BRICS (2017b). BRICS Leaders Xiamen Declaration + Action Plan. Point 1. Xiamen, 4 September. URL: http://mea.gov.in/Uploads/PublicationDocs/28912_XiamenDeclaratoin.pdf (accessed 19.09.2018).

${ }^{25}$ BRICS (2017b). BRICS Leaders Xiamen Declaration + Action Plan. Point 2. Xiamen, 4 September. URL: http://mea.gov.in/Uploads/PublicationDocs/28912_XiamenDeclaratoin.pdf (accessed 19.09.2018).

${ }^{26}$ BRICS (2016c). Goa Declaration + Action Plan. Points 26, 37. Goa, 16 October. URL: http://www.brics2018.org.za/sites/default/files/documents/Goa\%20Declaration.pdf (accessed 19.09.2018).

27 BRICS (2016c). Goa Declaration + Action Plan. Point 10. Goa, 16 October. URL: http://www.brics2018.org.za/sites/default/files/documents/Goa\%20Declaration.pdf (accessed 19.09.2018).

${ }^{28}$ BRICS (2016c). Goa Declaration + Action Plan. Point 3. Goa, 16 October. URL: http://www.brics2018.org.za/sites/default/files/documents/Goa\%20Declaration.pdf (accessed 19.09.2018).

${ }^{29}$ BRICS (2017b). BRICS Leaders Xiamen Declaration + Action Plan. Point 6. Xiamen, 4 September. URL: http://mea.gov.in/Uploads/PublicationDocs/28912_XiamenDeclaratoin.pdf (accessed 19.09.2018). 
for "the building of broad partnerships for development under the theme of 'Strengthening Mutually-Beneficial Cooperation for Common Development" "30. This is not just rhetoric. For example, Hopewell [Hopewell 2017] observes that enduring "strategic alignment" grounded in "solidarity" and "common interest", especially among Brazil, China and India in alliance with the vast majority of developing country governments within the World Trade Organization, has produced concrete transformations of the power structures in global trade governance in favour of the South. Nonetheless, an increasingly vocal position against "inward-looking policies" 31 within the rationale of an "open world economy" 32 may undermine the emancipatory potential of the BRICS model, as does the overall association of "development" (including "sustainable development", in alignment with the UN Sustainable Development Goals, SDGs) with economic growth, only marginally recognising the dialectics of the "economic, social and environmental" in "sustainable development"33.

Even though the New Development Bank is a "distinctive institution" in "normative" and "instrumental" terms — the first referring to the principles of "equality" and "mutual benefit", and the second to "product innovation" regarding the exclusive funding of small-scale (rather than large-scale) renewable energy projects - the reduction of "sustainable development" to "green infrastructure" and "green finance" [Cooper 2017] within a growth rationale fails to provide a genuinely alternative development paradigm [Sachs 2017]. Therefore, it may well be concluded that the BRICS project principally seeks to increase "access to, and representation in, the institutions and processes which define, administer and uphold international rules" ("contestation over representation") rather than challenging the underlying principles of the Westernled international liberal order ("normative contestation"), despite "some areas of genuine normative contestation" [Newman, Zala 2018: 871, 882] (also see footnote 19 in this article). That is, from Newman and Zala's more orthodox international relations perspective, BRICS displays an overwhelming adherence to the "substantive and procedural norms" that govern trade and development, peace and security, state sovereignty, international law and diplomatic practice, and "equity, justice and democracy" in international relations [Newman, Zala 2018: 875-877]. However, once the SSC principles and practices are included in the analysis, largely ignored by Newman and Zala, the BRICS project may especially since 2014/2015 represent a far greater normative challenge to the global governance of development than is frequently assumed. This is underscored by the suggestion that in the BRICS discourse, "national sovereignty" relates to resistance to the normative framework of North-led development assistance, especially the conditionalities and the "aid effectiveness agenda", and/or Western imperialism more generally [Abdenur 2014: 1883].

${ }^{30}$ BRICS (2017b). BRICS Leaders Xiamen Declaration + Action Plan. Point 69. Xiamen, 4 September. URL: http://mea.gov.in/Uploads/PublicationDocs/28912_XiamenDeclaratoin.pdf (accessed 19.09.2018).

${ }^{31}$ BRICS (2017b). BRICS Leaders Xiamen Declaration + Action Plan. Point 7. Xiamen, 4 September. URL: http://mea.gov.in/Uploads/PublicationDocs/28912_XiamenDeclaratoin.pdf (accessed 19.09.2018).

32 Ibid. Point 3.

33 Ibid. Point 14. 
The question that arises from the preceding discussion is: What role is ascribed to education in/for BRICS SSC, and what strategies seek to realise this? In the BRIC(S) summitry declarations 2009-2013, education is considered only twice in very general terms $^{34}$. However, with the 1st Meeting of the BRICS Ministers of Education in Paris in November 2013, within the context of the 37th session of the UNESCO General Conference (which formed the basis of the aforementioned UNESCO ${ }^{35}$ BRICS. Building Education for the Future report), intra-BRICS education cooperation gained in momentum. While the Fortaleza Declaration ${ }^{36}$ for the first time stresses the "strategic importance of education for sustainable development and inclusive economic growth", a common education agenda became established in 2015 via the Second and Third Meetings of BRICS Education Ministers and a Meeting of the BRICS Working Group on Educa$\operatorname{tion}^{37}$. This agenda was initially framed by the hegemonic "Education for All" and "Millennium Development Goals" "38, superseded since 2015 by the "Sustainable Development Goals", i.e. the education-related SDG4 with its objectives of "inclusive and equitable quality education" and "life-long learning opportunities for all" 39 .

The BRICS education discourse echoes the ambiguities inherent in the general summitry discourse. First, throughout 2015-2017, iterative reference to the general SSC ideas of "mutual interest", "mutual understanding" and "common interests" can be stated (in total 7 instances, see BRICS ${ }^{40}$ ), while use of existing "synergies" ${ }^{41}$ has subsequently

${ }^{34}$ BRIC (2009). Joint Statement of the BRIC Countries' Leaders. Point 11. Yekaterinburg, 16 June. URL: http://www.brics.utoronto.ca/docs/090616-leaders.html (accessed 02.03.2016); BRICS (2012). Delhi Declaration \& Action Plan. Point 48. New Delhi, 29 March. URL: http://www.brics.utoronto.ca/ docs/120329-delhi-declaration.html (accessed 23.02.2016).

${ }^{35}$ UNESCO (2014). BRICS: Building Education for the Future. Priorities for National Development and International Cooperation. Paris: UNESCO. URL: http://unesdoc.unesco.org/images/ 0022/002290/229054e.pdf.

36 BRICS (2014). Fortaleza Declaration \& Action Plan. Point 56. Fortaleza, 15 July. URL: http://www.brics.utoronto.ca/docs/140715-leaders.html (accessed 23.02.2016).

37 BRICS (2015b). Declaration of the II Meeting of BRICS Ministers of Education: Brasilia Declaration. Brasilia, 2 March. URL: http://www.brics.utoronto.ca/docs/150302-education.html (accessed 23.02.2016); BRICS (2015c). Conclusions. Meeting of the BRICS Working Group on Education. Moscow, 25-26 June. URL https://минобрнауки.рф/новости/5866/файл/6028/ Conclusions_26june\%202015.pdf (accessed 19.09.2018); BRICS (2015d). III Meeting of BRICS Education Ministers: Moscow Declaration. Moscow, 18 November. URL: en.brics2015.ru/load/791579 (accessed 19.09.2018).

${ }^{38}$ BRICS (2014). Fortaleza Declaration \& Action Plan. Point 56. Fortaleza, 15 July. URL: http://www.brics.utoronto.ca/docs/140715-leaders.html (accessed 23.02.2016).

39 BRICS (2016b). New Delhi Declaration on Education. New Delhi, 30 September. URL: https://nu-brics.ru/media/uploads/filestorage/New_Delhi_Declaration.pdf (accessed 19.09.2018); BRICS (2017a). Beijing Declaration of Education. Beijing, 5 July. URL: https://nu-brics.ru/media/ uploads/filestorage/beijing_declaration_1_1.pdf (accessed 19.09.2018).

${ }^{40}$ BRICS (2015b). Declaration of the II Meeting of BRICS Ministers of Education: Brasilia Declaration. Brasilia, 2 March. URL: http://www.brics.utoronto.ca/docs/150302-education.html (accessed 23.02.2016); BRICS (2015d). III Meeting of BRICS Education Ministers: Moscow Declaration. Moscow, 18 November. URL: en.brics2015.ru/load/791579 (accessed 19.09.2018); BRICS (2016b). New Delhi Declaration on Education. New Delhi, 30 September. URL: https://nu-brics.ru/media/ uploads/filestorage/New_Delhi_Declaration.pdf (accessed 19.09.2018); BRICS (2017a). Beijing Declaration of Education. Beijing, 5 July. URL: https://nu-brics.ru/media/uploads/filestorage/beijing declaration_1_1.pdf(accessed 19.09.2018). 
been omitted from the discourse. Second, in 2015 a discursive shift could be observed within the BRICS education discourse. Over that year "sharing" and "exchanging" of "best practices" 42 was replaced by "implementation" of "international best practices" while the neoliberal (anglo-centric) policy dimensions of "benchmarking" and "excellence" became discursively integrated in November $2015^{44}$. However, while "best practice sharing" re-entered the discourse in 2016 (replacing "implementation" of "international best practices"), the ideas of "benchmarking" and "excellence" have been abandoned ${ }^{45}$. While David and Motala remain inconclusive about the potential of BRICS providing "alternative meanings to the notions of 'world-class and 'excellence" [David, Motala 2017: 525], an equally pertinent issue raised by David and Motala is the incompatibility of solidarity cooperation and competition. That is, whether BRICS education cooperation serves the establishment of "world class universities" for competition in the global higher education market, or whether BRICS focuses on "national preferences" and on "common interests and problems of the group rather than global ranking" [David, Motala 2017: 520].

The outlined hybrid BRICS discourse provides some limited answers to these questions. Even though "solidarity" is absent in the BRICS education-related documents of 2015-2017, the "development of joint methodologies for education indicators" through "collaboration" in the form of "mutual technical support" serves "to support decision making in BRICS member states" $"$. This suggests that rather than developing indicators for competitive ends, as in the neoliberal project, here collective development is pursued: "cooperation in social and labour relations for establishing full-scale social, political and cultural cooperation and ensuring a qualitatively new level of external

${ }^{41}$ BRICS (2015b). Declaration of the II Meeting of BRICS Ministers of Education: Brasilia Declaration. Point 12. Brasilia, 2 March. URL: http://www.brics.utoronto.ca/docs/150302-education.html (accessed 23.02.2016).

42 Ibid. Points 3, 13.

${ }^{43}$ BRICS (2015c). Conclusions. Meeting of the BRICS Working Group on Education. Moscow, 25-26 June. Point 14. URL https://минобрнауки.рф/новости/5866/файл/6028/Conclusions 26june\%202015.pdf (accessed 19.09.2018); BRICS (2015d). III Meeting of BRICS Education Ministers: Moscow Declaration. Point 11. Moscow, 18 November. URL: en.brics2015.ru/load/791579 (accessed 19.09.2018).

${ }^{44}$ BRICS (2015d). III Meeting of BRICS Education Ministers: Moscow Declaration. Points 2 , 13, 14. Moscow, 18 November. URL: en.brics2015.ru/load/791579 (accessed 19.09.2018).

${ }^{45}$ BRICS (2015e). Memorandum of Understanding on Establishment of the BRICS Network University. Moscow, 18 November. URL: https://nu-brics.ru/media/uploads/filestorage/documents/ MoU_SU_BRICS.pdf (accessed 19.09.2018); BRICS (2016b). New Delhi Declaration on Education. New Delhi, 30 September. URL: https://nu-brics.ru/media/uploads/filestorage/New Delhi_Declaration.pdf (accessed 19.09.2018); BRICS (2017a). Beijing Declaration of Education. Beijing, 5 July. URL: https://nu-brics.ru/media/uploads/filestorage/beijing_declaration_1_1.pdf (accessed 19.09.2018).

${ }^{46}$ BRICS (2015b). Declaration of the II Meeting of BRICS Ministers of Education: Brasilia Declaration. Point 2. Brasilia, 2 March. URL: http://www.brics.utoronto.ca/docs/150302-education.html (accessed 23.02.2016); BRICS (2015c). Conclusions. Meeting of the BRICS Working Group on Education. Point 7. Moscow, 25-26 June. URL https://минобрнауки.рф/новости/5866/ файл/6028/Conclusions_26june\%202015.pdf (accessed 19.09.2018). 
relations for BRICS"47. As Dilvo Ristoff, Head of the Brazilian delegation in the BRICS meetings until August 2016 (during the Rousseff government), reports, the atmosphere in the meetings of BRICS representatives were always very cordial and productive. The BRICS partner countries treated each other "as equals and they were looking for a project of mutual interest, a university project that would contribute to the development of all the countries involved" [Ristoff 2016a].

At the same time, however, in accordance with the global education discourse (most recently the SDG4), commitment to equitable "lifelong learning opportunities for all" is a constant in the BRICS education agenda ${ }^{48}$. This coincides with aiming to integrate the "SDG4-related targets with the national and subnational-level education sector development plans/programmes" ${ }^{49}$. In 2015, education was viewed as an "investment" for the "development of human resources", and even "pre-school education" became instrumentalised for "skills and competencies development indispensable for innovative activities" 1 - that is, for economic growth. This narrow human capitalist view, however, has been superseded by associating higher education as a contribution not only to "the development of high-level human resources and intellectual support" for economic development, but also for "social development" 52 . This suggests that BRICS reasserts the role of education in/for development beyond economic ends, which is underscored by the overall BRICS education cooperation objective of fostering "cultural exchanges" via "people to people exchanges" ${ }^{33}$. While promoting "peopleto-people contact amongst the BRICS" entered the discourse in $2012^{54}$, this has only

47 BRICS (2015c). Conclusions. Meeting of the BRICS Working Group on Education. Moscow, 25-26 June. URL https://минобрнауки.рф/новости/5866/файл/6028/Conclusions_26june\%202015.pdf (accessed 19.09.2018).

${ }^{48}$ BRICS (2015b). Declaration of the II Meeting of BRICS Ministers of Education: Brasilia Declaration. Brasilia, 2 March. URL: http://www.brics.utoronto.ca/docs/150302-education.html (accessed 23.02.2016); BRICS (2015c). Conclusions. Meeting of the BRICS Working Group on Education. Moscow, 25-26 June. URL https://минобрнауки.рф/новости/5866/файл/6028/ Conclusions_26june\%202015.pdf (accessed 19.09.2018); BRICS (2015d). III Meeting of BRICS Education Ministers: Moscow Declaration. Moscow, 18 November. URL: en.brics2015.ru/load/791579 (accessed 19.09.2018). BRICS (2016b). New Delhi Declaration on Education. New Delhi, 30 September. URL: https://nu-brics.ru/media/uploads/filestorage/New_Delhi_Declaration.pdf (accessed 19.09.2018); BRICS (2017a). Beijing Declaration of Education. Beijing, 5 July. URL: https://nu-brics.ru/media/uploads/filestorage/beijing_declaration_1_1.pdf (accessed 19.09.2018).

${ }_{49}$ BRICS (2017a). Beijing Declaration of Education. Point 2. Beijing, 5 July. URL: https://nu-brics.ru/ media/uploads/filestorage/beijing_declaration_1_1.pdf (accessed 19.09.2018).

${ }^{50}$ BRICS (2015d). III Meeting of BRICS Education Ministers: Moscow Declaration. Point 17. Moscow, 18 November. URL: en.brics2015.ru/load/791579 (accessed 19.09.2018).

${ }^{51}$ BRICS (2015c). Conclusions. Meeting of the BRICS Working Group on Education. Point 8. Moscow, 25-26 June. URL https://минобрнауки.рф/новости/5866/файл/6028/Conclusions_ 26june\%202015.pdf (accessed 19.09.2018).

${ }_{52}$ BRICS (2017a). Beijing Declaration of Education. Beijing, 5 July. URL: https://nu-brics.ru/ media/uploads/filestorage/beijing_declaration_1_1.pdf(accessed 19.09.2018).

53 Ibid.

${ }^{54}$ BRICS (2012). Delhi Declaration \& Action Plan. Point 6. New Delhi, 29 March. URL: http://www.brics.utoronto.ca/docs/120329-delhi-declaration.html (accessed 23.02.2016). 
materialised since 2016, inter alia in the form of a film festival, a U-17 football tournament, and a youth summit ${ }^{55}$. Thus, arguably transcending mere inter-government/ inter-state relations, in 2017 this transnational dimension was declared "the third pillar of BRICS cooperation" 56 to "cultivate common values on the basis of diversity and sharing" $"$.

Education cooperation is now integrated in this "third pillar" 58 , and concrete initiatives include: the BRICS Network University (BRICS NU) and the BRICS University League; "cultural cooperation through language education and multilingualism"; "streamlining the cooperation among educational think tanks and education researchers"; "youth winter/summer camps"; scholarships; and advocacy for "global education policies that take into account the common concern and priorities of the BRICS Member States" ${ }^{59}$. In policy terms, this has been categorised as: Higher Education; Technical Vocational Education \& Training (TVET); General Education; and Educational Policy Strategy ${ }^{60}$. However, "higher education and research is a priority"61, whereby the BRICS Universities League (an "association of BRICS universities") ${ }^{62}$ and the BRICS NU have been created to promote "professionalization of academics" and the establishment of research networks, inter alia via master and $\mathrm{PhD}$ programmes [Smagina 2016] "in areas of mutual interest" ${ }^{\text {"64 }}$ : energy; computer science and information

55 BRICS (2016c). Goa Declaration + Action Plan. Goa, 16 October. URL: http://www.brics2018.org.za/sites/default/files/documents/Goa\%20Declaration.pdf (accessed 19.09.2018); BRICS (2017b). BRICS Leaders Xiamen Declaration + Action Plan. Points 63, 66. Xiamen, 4 September. URL: http://mea.gov.in/Uploads/PublicationDocs/28912_XiamenDeclaratoin.pdf (accessed 19.09.2018).

56 The other two pillars being "Political and Security Cooperation" and "Economic Cooperation" [BRICS (2017b). BRICS Leaders Xiamen Declaration + Action Plan. Annex 1. Xiamen, 4 September. URL: http://mea.gov.in/Uploads/PublicationDocs/28912_XiamenDeclaratoin.pdf (accessed 19.09.2018)].

57 BRICS (2017b). BRICS Leaders Xiamen Declaration + Action Plan. Point 60. Xiamen, 4 September. URL: http://mea.gov.in/Uploads/PublicationDocs/28912_XiamenDeclaratoin.pdf (accessed 19.09.2018).

58 BRICS (2017b). BRICS Leaders Xiamen Declaration + Action Plan. Annex 1. Xiamen, 4 September. URL: http://mea.gov.in/Uploads/PublicationDocs/28912_XiamenDeclaratoin.pdf (accessed 19.09.2018).

59 BRICS (2017a). Beijing Declaration of Education. Beijing, 5 July. URL: https://nu-brics.ru/ media/uploads/filestorage/beijing_declaration_1_1.pdf (accessed 19.09.2018).

${ }^{60}$ BRICS (2015d). III Meeting of BRICS Education Ministers: Moscow Declaration. Moscow, 18 November. URL: en.brics2015.ru/load/791579 (accessed 19.09.2018).

${ }^{61}$ BRICS (2015b). Declaration of the II Meeting of BRICS Ministers of Education: Brasilia Declaration. Point 8. Brasilia, 2 March. URL: http://www.brics.utoronto.ca/docs/150302-education.html (accessed 23.02.2016).

${ }^{62}$ Ibid. Point 9.

${ }^{63}$ BRICS (2017a). Beijing Declaration of Education. Point 3. Beijing, 5 July. URL: https://nu-brics.ru/ media/uploads/filestorage/beijing_declaration_1_1.pdf (accessed 19.09.2018).

${ }^{64}$ BRICS (2015b). Declaration of the II Meeting of BRICS Ministers of Education: Brasilia Declaration. Point 8. Brasilia, 2 March. URL: http://www.brics.utoronto.ca/docs/150302-education.html (accessed 23.02.2016). 
security; BRICS studies; ecology and climate change; water resources and pollution treatment; and economics ${ }^{65}$. Considered the "most ambitious BRICS project in the sphere of education and research" so far [Smagina 2016: 144], the BRICS NU is not a supranational institution but an international structure among BRICS NU National Coordination Committees, created in each member state by the education ministries, and financed by the participating universities ${ }^{66}$. While this Network University at its foundation stage integrates a maximum of 12 state universities from each BRICS member (in April 2016, a total 45 universities committed themselves to participating in the project) [Smagina 2016: 150], other initiatives within the BRICS education cooperation structure, such as the BRICS Scientific, Technological and Innovation (STI) Framework Programme for joint research projects among partners from at least three BRICS members, are also open to private not-for-profit institutions ${ }^{67}$. Ristoff, in personal electronic communication with the authors, reveals that Russia proposed the BRICS Network University and China contributed with the idea of a BRICS Universities League, with the understanding that "both are projects that complement each other" [Ristoff 2016a]. This occurs "in accordance with national guidelines, norms and regulations in each of the BRICS countries"68. For example, as Ristoff shows in a contribution to a newsletter published by the Ural Federal University (Russia), with respect to Brazil, the BRICS Network University and BRICS Universities League are in line with other internationalization efforts as considered in the National Education Plan 2014-2024: "(a) to promote scientific and technological exchange, national and international, between universities and (b) to raise the quality and quantity of scientific and technological activity of the country... expanding scientific cooperation [Ristoff 2016b: 17, italics original].

\section{CONCLUSION}

By transcending the mainstream approach to BRICS in the Anglophone academic literature, embedded in (neo)realist international relations theory, this article has presented a first evaluation of the South - South development and education agenda of BRICS as an analytical unit. While individual member governments may drive integration in the global higher education capitalism, such as China and India as "major 'sending' countries" of international students to "major English-speaking universities" [Altbach, Bassett 2014: 2], BRICS actively promotes the South-South principles

${ }^{65}$ BRICS (2015e). Memorandum of Understanding on Establishment of the BRICS Network University. Moscow, 18 November. URL: https:/nu-brics.ru/media/uploads/filestorage/documents/ MoU_SU_BRICS.pdf (accessed 19.09.2018).

${ }_{66}$ BRICS (2015e). Memorandum of Understanding on Establishment of the BRICS Network University. Article 13. Moscow, 18 November. URL: https://nu-brics.ru/media/uploads/filestorage/ documents/MoU_SU_BRICS.pdf (accessed 19.09.2018).

${ }^{67}$ BRICS (2016a). BRICS STI Framework Programme Coordinated call for BRICS multilateral projects — Pilot call 2016. URL: http://brics.rfbr.ru/rffi/eng/brics (accessed 13.09.2016).

68 BRICS (2015e). Memorandum of Understanding on Establishment of the BRICS Network University. Article 11. Moscow, 18 November. URL: https://nu-brics.ru/media/uploads/filestorage/ documents/MoU_SU_BRICS.pdf (accessed 19.09.2018). 
of solidarity, mutual benefits and self-reliance in an effort of generating "synergies" Despite such apparent contradictions, both in discourse and practice, and although it cannot be unambiguously concluded that BRICS education cooperation produces a counter-structure to the neoliberal global governance of education, we nonetheless perceive BRICS education cooperation as contributing to building a counter-dependency structure. In this, the BRICS NU may assume a key role, even though, many envisioned programmes (such as student exchanges) are not yet operational, and potentially resorting to English as lingua franca within the BRICS NU symbolically undermines the idea of a multipolar world. Future empirical research will have to inquire about the de facto implementation of this envisioned agenda.

Acknowledgements: We have no potential or actual conflicts of interest to declare.

\section{REFERENCES}

Abdenur, A.E. (2014). Emerging Powers as Normative Agents: Brazil and China within the UN Development System. Third World Quarterly, 35(10), 1876-1893. DOI: 10.1080/01436597.2014.971605.

Altbach, P.G. \& Bassett, R.M. (2014). Nix the BRICS — at least for Higher Education Scholarship. Change: The Magazine of Higher Learning, 46(5), 30-33. DOI: 10.1080/00091383.2014.941768.

Altbach, P.G., Reisberg, L., Yudkevich, M., Androushchak, G. \& Kuzminov, Y. (Eds.). (2013). The Global Future of Higher Education \& the Academic Profession: The BRICs and the United States. Basingstoke: Palgrave Macmillan.

Amin, S. (1980). Collective Self-reliance or National Liberation? In: Dialogue for a New Order. Ed. by K. Haq. New York: Pergamon, p. 153-169.

Azevedo, M.L.N. (2015). Higher Education and International Organizations: Cold War, Commodification, and the Global Field of Power. In: Liberation Psychology in Brazil. Ed. by S. Tuleski. New York: Nova, p. 13-39.

Birn, A.-E., Muntaner, C. \& Afzal, Z. (2017). South-South Cooperation in Health: Bringing in Theory, Politics, History, and Social Justice. Cadernos de Saúde Pública, 33(2), 37—52. DOI: 10.1590/0102-311X00194616.

Buzan, B., Held, D. \& McGrew, A. (1998). Realism vs Cosmopolitanism. Review of International Studies, 24 (3), 387-398.

Caporaso, J.A. (1978). Dependence, Dependency, and Power in the Global System: A Structural and Behavioral Analysis. International Organization, 32(1), 13-43.

Carnoy, M., Loyalka, P., Dobryakova, M., Dossani, R., Froumin, I., Kuhns, K., Tilak, J. \& Wang, R. (2013). University Expansion in a Changing Global Economy: Triumph of the BRICs? Stanford: Stanford University Press.

Chatin, M. \& Gallarotti, G.M. (2016). The BRICS and Soft Power: An Introduction. Journal of Political Power, 9 (3), 335-352. DOI: 10.1080/2158379X.2016.1232284.

Cheng, I-H. \& Chan, S-J. (Eds.). (2015). International Education Aid in Developing Asia: Policies and Practices. Dordrecht: Springer.

69 BRICS (2012). Delhi Declaration \& Action Plan. New Delhi, 29 March. URL: http://www.brics.utoronto.ca/docs/120329-delhi-declaration.html (accessed 23.02.2016); BRICS (2015a). Ufa Declaration \& Action Plan. Ufa, 9 July. URL: http://www.brics.utoronto.ca/docs/150709-ufadeclaration_en.html (accessed 23.02.2016); BRICS (2015b). Declaration of the II Meeting of BRICS Ministers of Education: Brasilia Declaration. Brasilia, 2 March. URL: http://www.brics.utoronto.ca/ docs/150302-education.html (accessed 23.02.2016). 
Cooper, A.F. (2017). The BRICS' New Development Bank: Shifting from Material Leverage to Innovative Capacity. Global Policy, 8 (3), 275-284. DOI: 10.1111/1758-5899.12458.

David, S.A. \& Motala, S. (2017). Can BRICS Build Ivory Towers of Excellence? Giving New Meaning to World-class Universities. Research in Comparative \& International Education, 12(4), 512-528. DOI: 10.1177/1745499917740652.

Dolowitz, D.P. \& Marsh, D. (2000). Learning from Abroad: The Role of Policy Transfer in Contemporary Policy-making. Governance: An International Journal of Policy and Administration, 13(1), 5-23. DOI: 10.1111/0952-1895.00121.

Erisman, M. (1991). Cuban Development Aid: South-South Diversification and Counterdependency Politics. In: Cuban Foreign Policy Confronts a New International Order. Ed. by M. Erisman and J. Kirk. London: Lynne Rienner, p. 139-165.

Ernst, D. (1979). La Cooperación Técnica entre los Países en Desarrollo. Comercio Exterior, 29 (12), 1396-1403. URL: http://revistas.bancomext.gob.mx/rce/magazines/443/11/RCE11.pdf.

Esteves, P. \& Assunção, M. (2014). South-South Cooperation and the International Development Battlefield: Between the OECD and the UN. Third World Quarterly, 35 (10), 1775-1790. DOI: $10.1080 / 01436597.2014 .971591$.

Fairclough, N. (2003). Analysing Discourse. London: Routledge.

Gallarotti, G.M. (2016). Compound Soft Power: The BRICS and the Multilateralization of Soft Power. Journal of Political Power, 9 (3), 467-490. DOI: 10.1080/2158379X.2016.1232292.

Gosovic, B. (2016). The Resurgence of South-South Cooperation. Third World Quarterly, 37 (4), 733-743. DOI: 10.1080/01436597.2015.1127155.

Hesse-Biber, S.N. (2017). The Practice of Qualitative Research: Engaging Students in the Research Process. Los Angeles: Sage.

Hopewell, K. (2017). The BRICS - Merely a Fable? Emerging Power Alliances in Global Trade Governance. International Affairs, 93 (6), 1377-1396. DOI: 10.1093/ia/iix192.

Jules, T.D. \& Sá e Silva, M.M. (2008). How Different Disciplines have Approached South—South Cooperation and Transfer. Society for International Education Journal, 5 (1), 45-64.

King, K. (2013). China's Aid and Soft Power in Africa. The Case of Education and Training. Woodbridge: James Currey.

Lalander, R. \& Lembke, M. (2018). The Andean Catch-22: Ethnicity, Class and Resource Governance in Bolivia and Ecuador. Globalizations, 15 (5), 636 - 654. DOI: 10.1080/14747731.2018.1453189.

Martín, R.D. (2016). En los Pliegues de la Historia: Cooperación Sur-Sur y Procesos de Integración en América Latina y el Caribe. Estudos Internacionais: Revista de Relações Internacionais, 4 (2), 57-77. DOI: 10.5752/P.2317-773X.2016v4.n2.p57.

Mason, J. (2002). Qualitative Researching ( $2^{\text {nd }}$ ed.). London: Sage.

Muhr, T. (2016). Beyond 'BRICS': Ten theses on South-South Cooperation in the 21st Century. Third World Quarterly, 37(4), 630 - 648. DOI: 10.1080/01436597.2015.1108161.

Newman, E. \& Zala, B. (2018). Rising Powers and Order Contestation: Disaggregating the Normative from the Representational. Third World Quarterly, 39 (5), 871-888. DOI: 10.1080/01436597.2017.1392085.

Nowak, M. (2003). Introduction to the International Human Rights Regime. Leiden/Boston: Brill Academic Publishers.

Nye, J.S. (2010). Responding to my Critics and Concluding Thoughts. In: Soft Power and US Foreign Policy. Ed. by I. Parmar and M. Cox. London: Routledge, p. 215-227.

Oleksiyenko, A. \& Yang, R. (2015). Nix the BRICs? Competitive and Collaborative Forces in the Ostensibly 'Blocalized' Higher Education Systems. Frontiers of Education in China, 10 (1), 1-6. DOI: 10.1007/BF033.

Phạm, Quỳnh N. \& Shilliam, R. (2016). Meanings of Bandung. Postcolonial Orders and Decolonial Visions. London: Rowman \& Littlefield. 
Report on South-South Cooperation in Ibero-America 2017. (2017). SEGIB (Ibero-American General Secretariat) Madrid: SEGIB.

Ristoff, D. (2016a). BRICS Rede de universidades. Personal digital communication, 17 September.

Ristoff, D. (2016b). International Cooperation in Higher Education: Trends and Challenges. InBRICS. BRICS Studies Centre Newsletter, 1, 10-18. URL: https://center-brics.urfu.ru/fileadmin/ user_upload/BRICS/br-br/InBRICS_ot_28_marta.pdf.

Robertson, S. \& Dale, R. (2008). Researching Education in a Globalising Era: Beyond Methodological Nationalism, Methodological Statism, Methodological Educationism and Spatial Fetishism. In: The Production of Educational Knowledge in a Global Era. Ed. by J. Resnick. Rotterdam: Sense Publishers, p. 19-32.

Sá e Silva, M.M. (2009). South-South Cooperation: Past and Present. Conceptualization and Practice. In: South-South Cooperation in Education and Development. Ed. by L. Chisholm and G. Steiner-Khamsi. New York: Teachers College Press, p. 39-59.

Sachs, W. (2017). The Sustainable Development Goals and Laudatio Si': Varieties of Post-Development? Third World Quarterly, 38 (12), 2537-2587. DOI: 10.1080/01436597.2017.1350822.

Santos, B.d.S. (2002). Toward a New Legal Common Sense. London: Butterworths.

Schwartzman, S., Pinheiro, R. \& Pillay, P. (2015). Higher Education in the BRICS Countries: Investigating the Pact between Higher Education and Society. Dordrecht: Springer.

Silva, J.G.d. (2018). Cooperación Sur-Sur y Triangular: El Papel de América Latina y el Caribe dentro del G-77 y China para Lograr la Primera Generación de un Mundo sin Hambre. Línea Sur, 13, 63-75.

Smagina, I. (2016). The First Forum of the BRICS Network University. BRICS Law Journal 3 (1), 144-151. DOI: 10.21684/2412-2343-2016-3-1-144-151.

Steiner-Khamsi, G. (2007). International Knowledge Banks and the Production of Educational Crises. In: Knowledge and Policy: Research — Information — Intervention. EEJR Roundtable. Ed. by I. Gogolin, E. Keiner, G. Steiner-Khamsi, J. Ozga and L. Yates. European Educational Research Journal, 6 (3), p. 285-292.

Stuenkel, O. (2016). Do the BRICS Possess Soft Power? Journal of Political Power, 9 (3), 353-367. DOI: $10.1080 / 2158379 X .2016 .1232285$.

Tünnermann Bernheim, C. (2009). Central America: Quality Assurance and Accreditation. In: Higher Education in Latin America and the Caribbean 2008. Ed. by F.L. Segrera, C. Brock and J.D. Sobrinho. Caracas: UNESCO/IESALC, p. 49-68.

Yin, R.K. (2009). Case Study Research. Design and Methods (4 ${ }^{\text {th }}$ ed.). London: Sage.

Received: 15.08 .2018

For citations: Muhr, T. \& Azevedo, M.L.N. (2018). The BRICS Development and Education Cooperation Agenda. Vestnik RUDN. International Relations, 18 (3), 517-534. DOI: 10.22363/2313-06602018-18-3-517-534.

\footnotetext{
About the Authors:

Thomas Muhr — PhD in Political Sociology, Assistant Professor, Social Development \& Policy, Habib University, Karachi, Pakistan; Honorary Assistant Professor, Centre for International Education Research (CIER), University of Nottingham, UK (e-mail: t.muhr2@gmail.com).

Mário Luiz Neves de Azevedo — PhD, Professor, Universidade Estadual de Maringá (Brasil) (e-mail: mario.de.azevedo@uol.com.br).
} 


\title{
РАЗВИТИЕ БРИКС И СОТРУДНИЧЕСТВО В ОБЛАСТИ ОБРАЗОВАНИЯ
}

\author{
T. Мyp \\ Университет Хабиба, Карачи, Пакистан, \\ Ноттингемский университет, Ноттингем, Великобритания
}

М.Л.Н. де Азеведо

Государственный университет Маринга, Маринга, Бразилия

Данная статья, в основу которой лег анализ довольно спорных толкований Буэнос-Айресского плана действий, нацелена на изучение в первом приближении итогов реализации программы развития БРИКС, прежде всего в области образования как примера сотрудничества по линии Юг-Юг. В методологическом плане автор опирался на теоретически подкрепленное кейс-исследование с использованием широкого круга примеров и пояснений. Аналитический обзор англоязычной академической литературы по проблематике образования в странах БРИКС в данном случае был объединен с анализом документальной базы по вопросам сотрудничества стран БРИКС в период с 2009 по 2017 г.

Хотя основная международная и компаративистская образовательная литература, встроенная в (нео) реалистическую теорию международных отношений, по-прежнему ограничивается изучением примеров отдельных стран БРИКС, использование критического подхода, связанного с теорией контрзависимости в контексте сотрудничества Юг-Юг, позволяет обойти методологическую «близорукость» через выявление общих повесток, проектов, интеракций и потенциальных синергий, формируемых в рамках БРИКС в качестве аналитических инструментариев. На фоне формирования более явной и убедительной повестки дня БРИКС как примера сотрудничества Юг-Юг достигнутые результаты все же еще не позволяют с уверенностью и однозначно утверждать, что сотрудничество БРИКС в области образования создает контрструктуру неолиберальной глобальной системе образования.

Тем не менее образовательный вектор сотрудничества БРИКС воспринимается автором как способствующий построению подобной структуры контрзависимости. В этой связи фокус внимания будущих эмпирических исследований должен быть нацелен на анализ результатов фактической реализации заявленной повестки дня. Юг-Юг

Ключевые слова: БРИКС; контрзависимость; развитие; образование; сотрудничество

Для цитирования: Muhr T., Azevedo M.L.N. The BRICS Development and Education Cooperation Agenda // Вестник Российского университета дружбы народов. Серия: Международные отношения. 2018. Т. 18. № 3. C. 517-534. DOI: 10.22363/2313-0660-2018-18-3-517-534.

Сведения об авторах: Томас Мур - доктор политических наук, доцент Университета Хабиба, Карачи, Пакистан; почетный доцент Центра международных исследований в области образования, Ноттингемский университет, Великобритания (e-mail: t.muhr2@gmail.com).

Марио Луис Невес де Азеведо - доктор философии, профессор Государственного университета Маринга, Бразилия (e-mail: mario.de.azevedo@uol.com.br). 